University of Nebraska - Lincoln

DigitalCommons@University of Nebraska - Lincoln

January 2001

\title{
Cladistic analysis of the pennatulacean genus Renilla Lamarck, 1816 (Coelenterata, Octocorallia)
}

Carlos D. Pérez

Laboratorio de Biología de Cnidarios (LABIC), Departamento de Ciencias Marinas, Facultad de Ciencias Exactas y Naturales, UNMdP, Funes 3250, 7600, Mar del Plata, Argentina

Federico C. Ocampo

University of Nebraska - Lincoln, focampo2@unl.edu

Follow this and additional works at: https://digitalcommons.unl.edu/entomologypapers

Part of the Entomology Commons

Pérez, Carlos D. and Ocampo, Federico C., "Cladistic analysis of the pennatulacean genus Renilla Lamarck, 1816 (Coelenterata, Octocorallia)" (2001). Papers in Entomology. 126.

https://digitalcommons.unl.edu/entomologypapers/126

This Article is brought to you for free and open access by the Museum, University of Nebraska State at DigitalCommons@University of Nebraska - Lincoln. It has been accepted for inclusion in Papers in Entomology by an authorized administrator of DigitalCommons@University of Nebraska - Lincoln. 
Published in Journal of Natural History 35:2 (January 2001), pp. 169-173; doi 10.1080/00222930150215305

Copyright (C) 2001 Taylor \& Francis Ltd. Used by permission.

http://www.tandf.co.uk/journals $\quad$ http://dx.doi.org/10.1080/00222930150215305

Accepted December 7, 1999.

\title{
Cladistic analysis of the pennatulacean genus Renilla Lamarck, 1816 (Coelenterata, Octocorallia)
}

\author{
Carlos D. Pérez ${ }^{1}$ and Federico C. Ocampo ${ }^{2}$ \\ ${ }^{1}$ CONICET. Laboratorio de Biología de Cnidarios (LABIC), Departamento de Ciencias \\ Marinas, Facultad de Ciencias Exactas y Naturales, UNMdP, Funes 3250, 7600, Mar \\ del Plata, Argentina; email: cdperez@mdp.edu.ar \\ ${ }^{2}$ Laboratorio de Sistemática y Biología Evolutiva (LASBE), Museo de la Plata, Paseo del \\ Bosque, 1900 La Plata, Argentina
}

\begin{abstract}
The genus Renilla is an interesting taxon for phylogenetic studies, which includes six species endemic to America with an anphiamerican distribution (Pacific-Atlantic Ocean). A cladistic analysis of Renilla Lamarck, 1816 using eight characters from external morphology produced one cladogram (length 14, $C I=0.92, R I=0.87$ ), and the characters were polarized using Echinoptilum macintoshii Hubrecht, 1885 as an outgroup. In the cladogram the following phylogenetic sequence results: $((R$. koellikeri ( $R$. muelleri, $R$. musaica)) (R. octodentata ( $R$. reniformis, $R$. tentaculata))).
\end{abstract}

Keywords: Coelenterata, Octocorallia, Renilla, cladogram, phylogeny.

\section{Introduction}

Phylogenetic studies on Octocorallia, such as Gerhart (1983) and Schmidt $(1972,1974)$ are still few; although Williams $(1994,1995 \mathrm{a}, \mathrm{b})$ provided the first modern phylogenetic analysis of the pennatulacean octocorals.

Williams (1995b) in his preliminary assessment of the phylogeny of Pennatulacea states:

Williams (1994) provided several reasons why cladistic analyses for lower metazoans such as the Pennatulacea are often seemingly intractable, explaining the consequent paucity of cladistic work in the literature regarding these taxa. These are: a) the scarcity of useful characters and the difficulty of character analysis; b) a poorly represented and problematic fossil record, which makes identification and comparison with extinct groups difficult or impossible (Conway-Morris, 1991); c) difficulty of obtaining fresh material of many taxa for study (especially for application of molecular and genetic techniques); d) a high frequency of homoplasy (parallelisms, convergences, reversals); and e) unusually high degrees of intraspecific variability. 
The family Renillidae is a group of pennatulacean octocorals that are very unlike other sea pens; for this reason it is very difficult to find a good outgroup. In the cladogram presented by Williams (1997) for various pennatulacean taxa, the genus Renilla occupies a basal position in the phylogeny of the Pennatulacea near the genera Veretillum and Echinoptilum, but in the other branch of the cladogram, because Renilla has bilateral symmetry and foliate rachis, these two synapomorphies locate the genus Renilla in the next upper level of the cladogram. Nevertheless, the family Echinoptilidae shares with the Renillidae more characters than other families of Pennatulacea (Table 1).

The genus Renilla is an interesting taxon for phylogenetic studies. It includes six species endemic to America and with an amphiamerican distribution (Pacific-Atlantic Ocean) (Zamponi and Pérez, 1995; Zamponi et al., 1997; Pérez, 1999). On the other hand the genus Echinoptilum Hubrecht, 1885 also includes six species but is distributed through the Indo-West Pacific from Hawaii to eastern Africa (Williams, 1990).

\section{Materials and methods}

The species analyzed were Renilla muelleri Kolliker, 1872; $R$. reniformis (Pallas, 1766); $R$. koellikeri (Pfeffer, 1886); R. musaica Zamponi and Pérez, 1995; R. octodentata Zamponi and Pérez, 1995; and R. tentaculata Zamponi, Pérez, and Capitoli, 1997. The characters were polarized using Echinoptilum macintoshii Hubrecht, 1885 as an outgroup. The collection numbers and data of species analyzed are listed in Appendix I.

The specimens examined are deposited in the invertebrate collections of the Argentine Museum of Natural Sciences "Bernardino Rivadavia" and Museum of La Plata, in the collections of coelenterates of the Laboratory of Cnidarian Biology (Marine Science Department, National University of Mar del Plata, Argentine), and also in the Laboratory of Ecology of Benthic Invertebrates (Fundação Universidade Rio Grande, Brasil).

\section{Phylogenetic methods}

Outgroup. The genus Echinoptilum was here chosen as the outgroup to the genus Renilla on the following basis. These genera share some features such as: absence of axis; adjacent polyps freely distributed directly on the rachis; autozooids retractile in distinctive calyces armed with calicinal teeth; presence of sclerites, three-flanged spindles and colonies radially to bilaterally symmetrical. Within the genus Echinoptilum, E. macintoshii was the chosen spe-

Table 1. Data matrix used in the cladistic analysis of genus Renilla.

$0=$ plesiomorphic; $1,2,3,4=$ apomorphic

\begin{tabular}{|c|c|}
\hline Species & $\begin{array}{l}\text { Characters } \\
12345678\end{array}$ \\
\hline Echinoptilum macintoshii & 00000000 \\
\hline R. koellikeri & 00101111 \\
\hline R. muelleri & 01111311 \\
\hline R. musaica & 00111311 \\
\hline R. octodentata & 01003411 \\
\hline$R$. reniformis & 10002211 \\
\hline R. tentaculata & 20002111 \\
\hline
\end{tabular}


cies because the shape of calyx teeth is similar to that of the genus Renilla in being conical to deltoid. Consequently, E. macintoshii is considered the pennatulacean taxon closest to the $R e$ nilla clade.

Characters and polarity. The characters used were derived from the external morphology (Table 1). Apomorphic character states were identified and polarized by outgroup comparison (Brooks and McLennan, 1991; Nixon and Carpenter, 1993) with the species Echinoptilum macintoshii. Multistate characters 1 and 5 were treated as additive multistate, in both characters we follow the logic sequence of the different states. Character 6 was treated as non-additive because we found it impossible to establish a sequence between different states. Analysis was carried out with Hennig 86 version 1.5 (Farris, 1988), applying the implicit enumeration option, and consistency $(\mathrm{CI})$ and retention $(\mathrm{RI})$ indices were calculated.

List of characters. The characters listed below are summarized in the matrix of table 1.

1. Peduncle length: (0) short, (1) long, (2) very long.

2. Sclerite length: (0) shorter on the peduncle, (1) uniform.

3. Color of the sclerites: (0) with color variation, (1) uniform color.

4. Medium dorsal tract free of polyps: (0) present, (1) absent.

5. Number of calicinal teeth: (0) with two teeth, (1) with five teeth, (2) with seven teeth, (3) with eight teeth.

6. Rachis shape: (0) digitiform, (1) heart-round, (2) kidney-heart-round, (3) kidney-horseshoe, (4) kidney-bilobulate.

7. Sclerites: (0) three-flanged rods and ovals, (1) three flanged rods.

8. Polyp distribution: (0) all around the rachis, (1) dorsal only.

\section{Cladistic results}

The analysis of the data matrix (Table 1) produced one cladogram with 14 steps, a consistence index $C I=0.92$ and retention index $R I=0.87$ (Figure 1).

The genus Renilla is defined for two synapomorphies: "sclerites with three-flanged rods" and "dorsal-polyp distribution." The cladistic analysis allowed the identification of two lineages formed for: one, R. koellikeri, R. muelleri and $R$. musaica, defined for the synapomorphies "uniform color of the sclerites" and "number of calicinal teeth: 5"; and the other, $R$. octodentata, $R$. reniformis, and $R$. tentaculata defined for the synapomorphy "number of calicinal teeth: 7." In the first group the species $R$. koellikeri and $R$. musaica are related for the synapomorphies "medium dorsal tract free of polyps present" and "rachis shape kidney-horseshoe"; in the second group the species $R$. reniformis and $R$. tentaculata are related for the synapomorphy "peduncle long"; there is parallelism, "sclerites length uniform," between $R$. muelleri and R. octodentata.

\section{Discussion}

The species here assigned to the genus Renilla form a natural group defined by synapomorphies derived from the morphology. The cladogram obtained accords with the previous biological and taxonomic thinking (Zamponi and Pérez, 1995; Zamponi et al., 1997; Pérez, 1999). Two groups are defined, one, "muelleri group" (R. muelleri, R. koellikeri, and R. musaica ) and the other "reniformis group" ( $R$. reniformis, $R$. octodentata, and R. tentaculata). 


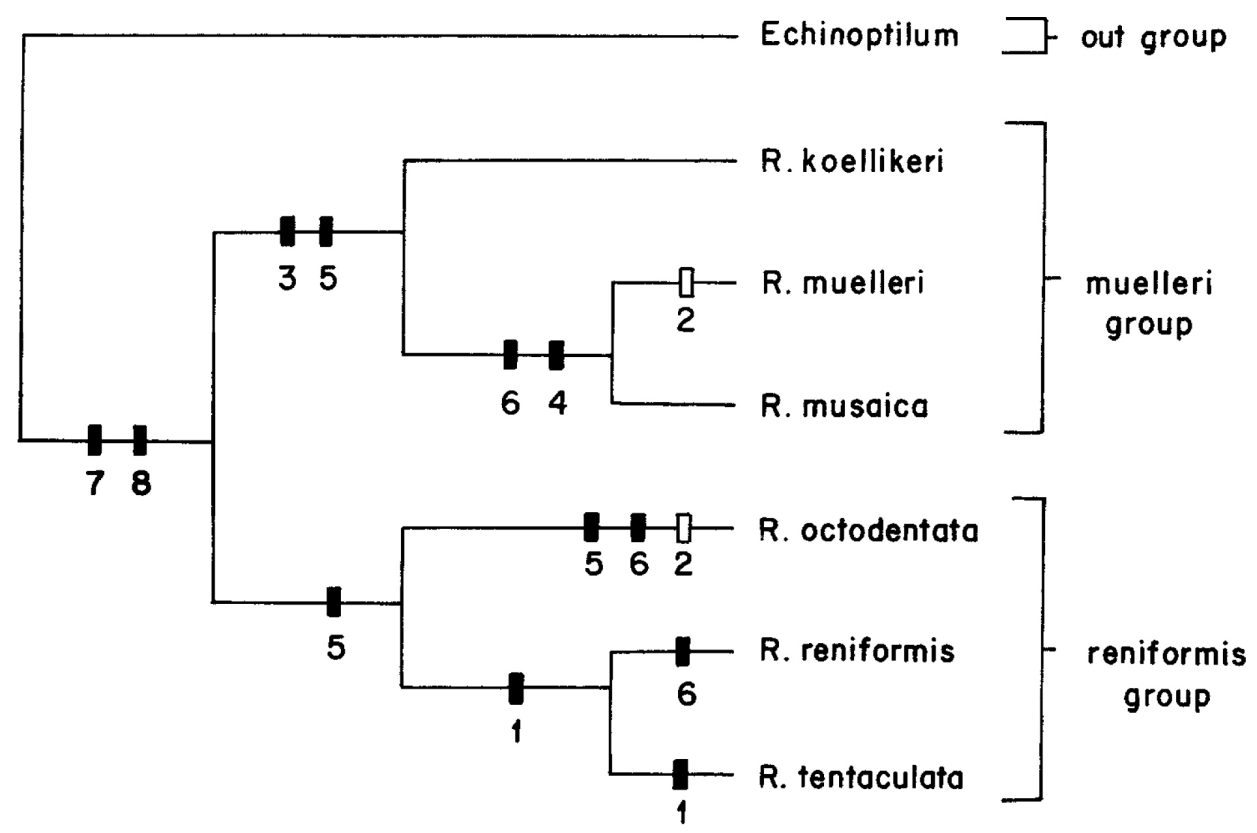

Figure 1. Cladogram of the genus Renilla. Node numbers refer to eight characters used in the analysis.

The next step for a further study of the genus Renilla will be to carry out a panbiogeographic study, and the combination of cladistics and panbiogeography may give us an approximation of the history of this interesting genus.

\section{Acknowledgements}

We thank to Dr. Mauricio O. Zamponi (Universidad Nacional de Mar del Plata, Mar del Plata) for his contributions to form the primary idea of this work. We are grateful to Dr. Gary Williams (California Academy of Sciences, California) and Dr. Jorge V. Crisci (Museo La Plata, La Plata) for critically reviewing the manuscript and for their timely comments. We also thank Cart. Carmen Milloc (Laboratory of Cartography, Universidad Nacional de Mar del Plata, Mar del Plata) for drawing of the cladogram.

\section{References}

Brooks, D. R. and McLennan, D. A., 1991. Phylogeny, Ecology, and Behavior. (Chicago: University of Chicago Press), $434 \mathrm{pp}$.

Conway Morris, S., 1991, Problematic taxa: a problem for biology or biologists? in A. M. Simonetta and S. Conway Morris (eds.), The early evolution of Metazoa and the significance of problematic taxa. (New York: Cambridge University Press), pp. 19-24.

Gerhart, D. J., 1983, The chemical systematic of colonial marine animals: an estimated phylogeny of the order Gorgonacea based on terpenoid characters, Biological Bulletin, 164, 71-81.

Farris, J. S., 1988, Hennig 86 reference. Version 1.5. (Port Jefferson, New York: Published by the author).

Nixon, K. C. and Carpenter, J. M., 1993, On outgroups, Cladistics, 9, 413-426. 
Pérez, C. D., 1999, Taxonomía, distribución y diversidad de los Pennatulacea, Gorgonacea y Alcyonacea del Mar Epicontinental Argentino y zonas de influencia. Doctoral thesis, Universidad Nacional de Mar del Plata, Mar del Plata, xviii $+254 \mathrm{pp}$.

Schmidt, H., 1972, Die Nesselkapseln der Anthozoa und ihre Bedeutung fur die phologenetische Systematik, Helgolander wiss. Meers., 23, 422-458.

Schmidt, H., 1974, On the evolution of the Anthozoa, Proceedings 2nd International Coral Reef Symposium, 1, 533-560.

Williams, G. C., 1990, The Pennatulacea of Southern Africa (Coelenterata, Anthozoa), Annals of the South African Museum, 99 (4), 31-119.

Williams, G. C., 1994, Biotic diversity, biogeography and phylogeny of pennatulacean octocorals associated with coral reefs in the Indo-Pacific, Proceedings 7th International Coral Reef Symposium, 1992, 2, 729-735.

Williams, G. C., 1995a, The enigmatic sea pen genus Gyrophyllum - a phylogenetic assessment and description of G. sibogae from Tasmanian waters (Coelenterata: Octocorallia), Proceedings of the California Academy of Sciences, 48 (15), 315-328.

Williams, G. C., 1995b, Preliminary assessment of the phylogeny of Pennatulacea (Anthozoa: Octocorallia), with a re-evaluation of Ediacaran frond-like fossils, and a synopsis of the history of evolutionary thought regarding the sea pens, Proceedings 6th International Conference on Coelenterate Biology, 1995, 497-509.

Williams, G. C., 1997, Octocorallia, in David and Wayne Maddison (eds.), Tree of Life World Wide Web Project (Tucson: University of Arizona); http://ag.arizona.edu/tree/phylogeny.html

Zamponi, M. O. and Pérez, C. D., 1995, Revision of the pennatulacean genus Renilla Lamarck, 1816 (Octocorallia, Pennatulacea), with descriptions of two new species from the Subantarctic region, Miscellania Zoologica, 18, 21-32.

Zamponi, M. O., Pérez, C. D., and Capitoli, R., 1997, El gènero Renilla Lamarck, 1816 (Anthozoa, Pennatulacea) en aguas de plataforma del sur brasilero, Annali di Museo Civico de Historia Naturale 'G. Doria', XCI, 541-553.

\section{Appendix I. Material examined}

The following list refers to specimens examined in the present study. Abbreviations are: ex., specimens examined; st., station; m, meters; DCM CP, Department of Marine Science Collection of Pennatulacea (University of Mar del Plata, Argentine); MACN, Argentine Museum of Natural Sciences "Bernardino Rivadavia" (Buenos Aires, Argentine)

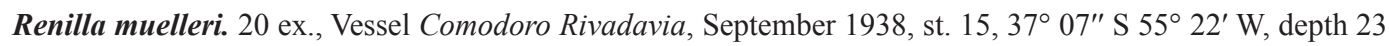
m., DCM CP 6.

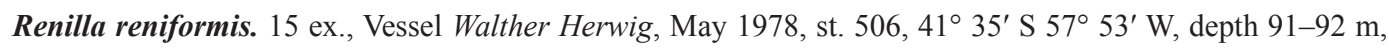
DCM CP 7.

Renilla octodentata. 4 ex., Vessel Oca Balda, May 1988, st. 37, 44 $48^{\prime} \mathrm{S} 65^{\circ} 30^{\prime} \mathrm{W}$, depth 65m, MACN no. 25397.

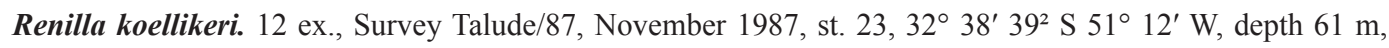
DCM CP 13.

Renilla musaica. 2 ex., Vessel Presidente Mitre, February 1955, 39 59' S 56 $16^{\circ}$ W, depth 100-200m, MACN no. 8528.

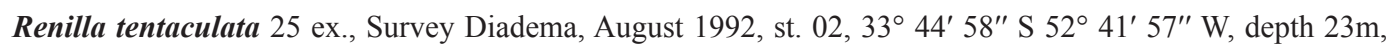
MACN 33815. 